\title{
PENDAMPINGAN DAN KONSELING ASI BERPENGARUH TERHADAP PENGETAHUAN, MOTIVASI DAN PERILAKU IBU DALAM MENYUSUI
}

\author{
Mariani $^{1)}$, Sunanto ${ }^{2)}$, Shinta Wahyusari ${ }^{3)}$ \\ Proram Studi Diploma Keperawatan, STIKES Hafshawaty Pesantren Zainul Hasan \\ Program Studi Sarjana Keperawatan, STIKES Hafshawaty Pesantren Zainul Hasan \\ email: mariakenby@gmail.com
}

\begin{abstract}
Abstrak
ASI merupakan makanan terbaik bagi bayi karena mengandung zat gizi yang lengkap untuk kebutuhan bayi. Secara umum, cakupan ASI eksklusif di Indonesia khususnya di Kabupaten Probolinggo tahun 2017 mengalami penurunan. Salah satu penyebab yang dapat diidentifikasi yaitu kurangnya persiapan selama hamil. Salah satu upaya yang dilakukan adalah melalui pendampingan dan konseling. Penelitian ini bertujuan untuk mengetahui pengaruh pelaksanaan pendampingan dan konseling ASI terhadap pengetahuan, motivasi, dan perilaku ibu dalam menyusui. Penelitian ini menggunakan pre eksperimental design yang berbentuk post test only design with control group. Populasi dalam penelitian ini adalah seluruh ibu hamil trimester tiga di BPM Wilayah kerja Puskesmas Pajarakan. Sampel dipilih menggunakan accidental sampling dan didapatkan sebanyak 30 responden yang dibagi menjadi dua yaitu kelompok perlakuan dan kelompok kontrol. Analisis data menggunakan uji Mann Whitney untuk mengukur perbedaan pengetahuan, motivasi, dan perilaku ibu dalam menyusui antara kelompok kontrol dan perlakuan. Hasil penelitian menunjukkan bahwa ada perbedaan yang signifikan pada pengetahuan $(\mathrm{p}=0,000 ; \mathrm{p}<0,05)$, motivasi $(\mathrm{p}=0,000 ; \mathrm{p}<0,05)$, dan perilaku $(\mathrm{p}=0,000 ; \mathrm{p}<$ $0,05)$ ibu dalam menyusui antara kelompok perlakuan dan kelompok kontrol. Pelaksanaan pendampingan dan konseling ASI berpengaruh terhadap keberhasilan menyusui. Diharapkan pendampingan dan konseling ASI dapat menjadi program dalam meningkatkan capaian pemberian ASI eksklusif.
\end{abstract}

Kata kunci : pendampingan, konseling ASI, pengetahuan, motivasi, perilaku.

\begin{abstract}
ASI is the best food for babies, because it contains complete nutrients for the baby's needs. In general, coverage of exclusive breastfeeding in Indonesia, especially in Probolinggo District in 2017 has decreased. One identifiable cause is lack of preparation during pregnancy. One effort that can be done is through breastfeeding assistance and counseling. This study aimed to determine the effect of the implementation of breastfeeding assistance and counseling on the knowledge, motivation, and behavior of breastfeeding mothers. This research method used a pre experimental design in the form of a post test only design with control group. The population in this study was all third trimester pregnant women in BPM Pajarakan Community Health Center. Samples were selected using accidental sampling and the number of samples obtained is 30 respondents divided into two groups namely the treatment group and the control group. Data analysis used the Mann Whitney test to measure differences in knowledge, motivation, and behavior of mothers in breastfeeding between the control and treatment groups. The results showed that there were significant differences in knowledge $(p=0,000 ; p<0.05)$, motivation ( $p=0,000 ; p<0.05)$, and behavior ( $p=0,000 ; p<0.05)$ of mothers in breastfeeding between the treatment group and the control group. Implementation of assistance and lactation counseling affect the success of breastfeeding. It is expected that the ASI mentoring and counseling process can become a program in increasing the achievement of exclusive breastfeeding.
\end{abstract}

Keywords : assistance, lactation counseling, knowledge, motivation, behavior. 


\section{PENDAHULUAN}

Air susu ibu (ASI) merupakan makanan yang sempurna dan terbaik bagi bayi, karena ASI mengandung zat gizi yang lengkap untuk kebutuhan bayi. Disamping itu, ASI juga banyak memiliki manfaat tidak hanya bagi bayi tetapi juga ibu, sehingga ASI menjadi faktor penting bagi pertumbuhan bayi. Namun demikian capaian pemberian ASI eksklusif masih saja jauh dari target. Salah satu penyebab masih rendahnya cakupan pemberian ASI eksklusif pada bayi usia kurang dari enam bulan yaitu salah satunya karena faktor produksi ASI yang masih sedikit pada hari-hari pertama pasca persalinan dan ibu merasa ASI nya tidak cukup. Padahal masalah yang sebenarnya karena kurangnya dukungan dari orang terdekat, masalah fisik dan emosi, pilihan ibu yang membatasi ASI, dan kekhawatiran ASI kurang. Oleh karena itu sebagian besar ibu memberikan susu formula pada saat bayi baru lahir. Hal tersebut merupakan salah satu penyebab angka kematian bayi (AKB) di Indonesia masih tinggi. Menurut Depkes (2011), Kematian bayi di Indonesia diperkirakan lebih banyak terjadi pada usia 0-28 hari (Neonatus) yang disebabkan karena Asfiksia, berat badan lahir rendah (BBLR), penyakit infeksi, penyakit lain dan masalah gizi. Salah satu intervensi yang dapat dilakukan untuk mengurangi angka kematian bayi diantaranya adalah dengan pemberian Air susu ibu (ASI). (Dirjen Bina Gizi dan Balita Kemenkes, 2013).

\section{METODE PENELITIAN}

Penelitian ini menggunakan metode penelitian pre eksperimental design yang berbentuk post test only design with control group yaitu pengukuran hanya dilakukan setelah diberikan perlakuan. Penelitian ini dilakukan pada bulan JuniAgustus di Bidan Praktik Mandiri (BPM) Wilayah Puskesmas Pajarakan Probolinggo. Partisipan dalam penelitian ini adalah ibu hamil trimester III. Dengan menggunakan Tehnik Accidental Sampling sehingga diperoleh sampel 30 partisipan dan dibagi menjadi dua kelompok yaitu kontrol dan perlakuan. Pengumpulan data diambil dengan menggunakan kuisioner, kemudian ditabulasi data diuji menggunakan uji Mann Whitney.

Variabel bebas dalam penelitian ini adalah pendampingan dan konseling. Variabel terikat adalah pengetahuan, motivasi dan perilaku ibu dalam menyusui. Instrumen pengumpulan data untuk pengetahuan dan motivasi menggunakan lembar kuesioner dan untuk perilaku ibu menggunakan lembar observasi pengamatan menyusui dari modul konseling 40 jam dari WHO.

\section{HASIL DAN PEMBAHASAN}

\section{Data Karakteristik Responden}

Tabel 1. Karakteristik Responden Berdasarkan Usia, Tingkat Pendidikan, Pekerjaan, Suku, Paritas, dan Pengalaman Menyusui

\begin{tabular}{cccc}
\hline Var & & Frekuensi (f) & Persentase (\%) \\
\hline \multirow{3}{*}{ USIA } & $<20$ thn & 1 & 3 \\
& $>20-25$ & 12 & 30 \\
\multirow{5}{*}{ Tingkat Pendidikan } & $>25-30$ & 11 & 20 \\
& $>30$ & 6 & 3,3 \\
& SD & 1 & 16,7 \\
\multirow{2}{*}{ Pekerjaan } & SMP & 5 & 76,7 \\
& SMA & 23 & 3,3 \\
& PT & 1 & 90 \\
& IRT & 27 & 10 \\
\hline
\end{tabular}




\begin{tabular}{cccc}
\hline \multirow{2}{*}{ Suku bangsa } & Jawa & 24 & 80 \\
& Madura & 6 & 20 \\
Paritas & Primipara & 11 & 36,7 \\
& Multipara & 19 & 63,3 \\
& 0 tahun & 11 & 36,7 \\
Pengalaman & $<1$ tahun & 1 & 3,3 \\
Menyusui & $1-2$ tahun & 16 & 53,3 \\
& $>2$ tahun & 2 & 6,7 \\
\hline
\end{tabular}

Berdasarkan tabel diatas menunjukkan bahwa sebagian besar usia responden adalah $>20-25$ tahun $(40 \%)$, tingkat pendidikan ibu adalah SMA (76,7\%), dengan pekerjaan IRT
(90\%), suku bangsa Jawa (80\%), multipara $(63,3 \%)$ dan memiliki pengalaman menyusui $1-2$ tahun $(53,3 \%)$.

\section{Pengaruh pelaksanaan pendampingan dan konseling menyusui terhadap pegetahuan,} motivasi dan perilaku ibu dalam menyusui

Tabel 2. Analisis Hasil Uji Mann Whitney pada pegetahuan, motivasi dan perilaku ibu dalam menyusui

\begin{tabular}{cllccc}
\hline \multicolumn{1}{c}{ Var } & & Median (Min-Max) & SD & 95\% CI & p \\
\hline Pengetahuan & Intervensi & $95(90-100)$ & 4,419 & $92,89-97,78$ & 0,000 \\
& Kontrol & $50(35-65)$ & 7,480 & $47,52-55,81$ & \\
Motivasi & Intervensi & $90(85-100)$ & 5,627 & $91,22-97,45$ & 0,000 \\
& Kontrol & $50(45-65)$ & 6,172 & $49,92-56,75$ & \\
Perilaku & Intervensi & $95(90-100)$ & 3,994 & $94,12-98,55$ & 0.000 \\
& Kontrol & $60(40-70)$ & 10,328 & $49,95-61,39$ & \\
\hline
\end{tabular}

Berdasarkan hasil analisis menggunakan uji mann whitney pada tabel 3 dapat diketahui bahwa perbedaan yang signifikan pada pengetahuan antara kelompom perlakuan dengan kelompok kontrol dengan nilai pvalue $0,000(\rho<0,05)$. Pada variabel motivasi juga didapatkan perbedaan yang signifikan antara kelompok perlakuan dengan kelompok kontrol dengan nilai $\rho$ value $0,000(\rho<0,05)$. Sedangkan pada variabel perilaku didapatkan perbedaan yang signifikan antara kelompok perlakuan dengan kelompok kontrol dengan nilai $\rho$ value $0,000(\rho<0,05)$.

\section{Pembahasan}

Pengaruh pelaksanaan pendampingan dan konseling menyusui terhadap pengetahuan ibu tentang proses menyusui

Berdasarkan hasil penelitian, didapatkan bahwa terdapat perbedaan yang signifikan pada pengetahuan ibu tentang proses menyusui antara kelompok perlakuan dan kelompok kontrol $(\mathrm{p}=0,000)$. Hal ini sejalan dengan penelitian yang dilakukan oleh Ambarwati (2013) yang menunjukkan bahwa konseling laktasi dapat meningkatkan pengetahuan ibu tentang menyusui dibandingkan dengan kelompok kontrol.

Salah satu peran konselor laktasi adalah melakukan edukasi dan memberikan dukungan kepada ibu menyusui. Edukasi yang diberikan dapat menggunakan berbagai media seperti booklet, video, leaflet, lembar balik serta menggunakan metode demonstrasi dan pendampingan selama proses menyusui. Edukasi tentang laktasi dapat meningkatkan pengetahuan ibu menyusui tentang ASI eksklusif. Hal ini sejalan dengan penelitian yang dilakukan oleh Merdhika, Mardji, \& Dewi (2014) yang menggunakan buku saku sebagai media dalam memberikan edukasi terhadap ibu menyusui. Selain itu, penelitian tersebut juga menggunakan metode simulasi sehingga memudahkan ibu dalam memahami materi yang disampaikan. Penggunaan dua metode tersebut telah terbukti dapat meningkatkan pengetahuan ibu menyusui karena dapat memacu semangat ibu dalam mempelajari materi tentang ASI eksklusif. 
Faridah (2017) melakukan penelitian terhadap 24 ibu menyusui di RSU Ponorogo. Hasil penelitian tersebut menunjukkan bahwa terdapat perbedaan pengetahuan ibu menyusui tentang teknik menyusui yang benar sebelum dan sesudah dilakukan penyuluhan. Responden yang digunakan pada penelitian tersebut sebagian besar merupakan ibu primipara yang belum memiliki pengalaman dalam menyusui. Dengan diberi penyuluhan, pengetahuan ibu dapat meningkat secara signifikan dan ibu termotivasi untuk mempraktekkan sendiri tentang materi yang telah diajarkan.

Tingkat pengetahuan merupakan faktor penting dalam membantu keberhasilan pelaksanaan pemberian ASI eksklusif. Hasil dari beberapa penelitian menunjukkan bahwa ibu yang tidak memberikan ASI eksklusif terhadap bayi disebabkan karena ibu kurang memahami manfaat pemberian ASI (Lystyaningrum \& Vidayanti, 2016). Hal ini sejalan dengan penelitian sebelumnya yang dilakukan oleh Diana (2007) yang menyatakan bahwa terdapat beberapa faktor yang dapat mempengaruhi ASI eksklusif yaitu tingkat pengetahuan ibu menyusui, adanya mitos kurang baik yang beredar di kalangan masyarakat, serta ibu bekerja.

\section{Pengaruh pelaksanaan pendampingan dan konseling menyusui terhadap motivasi ibu tentang proses menyusui}

Berdasarkan hasil penelitian, didapatkan bahwa terdapat perbedaan yang signifikan pada motivasi ibu tentang proses menyusui antara kelompok perlakuan dan kelompok kontrol $(\mathrm{p}=0,000)$. Pada kelompok kontrol, ibu tidak dilakukan konseling dan pendampingan dalam proses menyusui, sehingga ibu tidak memiliki kesempatan untuk mendapatkan informasi yang lebih tentang proses menyusui. Hal ini berbeda dengan kelompok perlakuan yang mendapat konseling menyusui dan pendampingan, sehingga ibu memiliki lebih banyak kesempatan untuk kontak dengan petugas kesehatan sehingga mendapat informasi yang lebih banyak terkait proses menyusui dan ibu lebih termotivasi dalam memberikan ASI kepada bayi.

Terbentuknya motivasi individu dapat dikarenakan adanya suatu kebutuhan untuk mencapai tujuan. Motivasi dikatakan kuat jika seseorang memiliki keinginan yang positif, memiliki harapan dan keyakinan yang tinggi dalam melakukan aktivitas untuk menghadapi persolan sehari-hari.

Salah satu faktor yang dapat mempengaruhi motivasi ibu dalam memberikan ASI eksklusif adalah tingkat pengetahuan. Pada penelitian ini, tingkat pengetahuan ibu meningkat karena adanya perlakuan yaitu pendampingan dan konseling ASI selama proses menyusui.

Ibu yang memiliki motivasi yang kuat dalam memberikan ASI dapat ditunjukkan dalam berbagai perilaku seperti melakukan berbagai upaya untuk meningkatkan produksi ASI dengan mengkonsumsi berbagai makanan yang dipercaya dapat memperlancar produksi ASI. Ibu juga yakin bahwa ASI penting untuk bayi karena memberikan manfaat yang besar terhadap bayi yaitu mencerdaskan otak dan mempercepat pertumbuhan dan perkembangan, serta dapat meningkat tali kasih sayang antara bayi dan ibu (Afifah, 2007).

Peran konselor laktasi telah terdokumentasi pada periode prenatal dan segera setelah lahir yang merupakan periode yang krusial dalam proses menyusui. konselor ASI berfungsi untuk memberikan edukasi antenatal dan memberikan dukungan pada periode postnatal. Fokus pada kegiatan tersebut adalah konseling dan membantu ibu menyusui dalam menyelesaikan masalah selama proses menyusui.

\section{Pengaruh pelaksanaan pendampingan dan konseling menyusui terhadap perilaku ibu dalam menyusui}

Berdasarkan hasil penelitian, didapatkan bahwa terdapat perbedaan yang signifikan pada kemampuan ibu dalam memberikan ASI antara kelompok perlakuan dan kelompok kontrol $(p=0,000)$. Hal ini sejalan dengan hasil penelitian yang dilakukan oleh Vidayanti \& Wahyuningsih (2017) yaitu terdapat perbedaan perilaku ibu dalam menyusui yang signifikan antara kelompok kontrol dan intervensi pada ibu yang mengalami bedah sesar.

Pada penelitian tersebut, konselor melakukan kontak pertama dengan melakukan pendekatan pada ibu pasca bedah sesar melalui ketrampilan mendengarkan dan mempelajari permasalahan yang dialami responden, memberikan pertanyaan terbuka, menggunakan gerakan tubuh untuk 
menunjukkan perhatian, dan melakukan demonstrasi tentang cara menyusui yang benar. Penelitian lain juga menyebutkan bahwa pemberian konseling menyusui dapat meningkatkan keberhasilan ibu dalam menyusui bayinya (Mariani \& Hamim, 2018).

Faktor yang dapat membentuk kemampuan atau keterampilan salah satunya adalah pengetahuan. Pengetahuan merupakan faktor penting dalam membentuk perilaku seorang ibu dalam memberikan ASI. Tingkat pengetahuan yang tinggi dapat berdampak pada keterampilan seseorang dalam menghadapi masalah terutama yang berhubungan dengan pemberian ASI. Faktor lain yang mempengaruhi kemampuan ibu dalam memberikan ASI yaitu adanya pengalaman menyusui sebelumnya.

Responden dalam penelitian ini sebagian besar merupakan ibu multipara yang telah memiliki pengalaman dalam menyusui. Ibu multipara dengan usia yang lebih tua dianggap memiliki pengetahuan yang lebih jika dibandingkan dengan ibu primipara dalam hal menyusui. Namun hal ini tergantung pada ibu sendiri dalam

\section{REFERENSI}

Afifah, Diana Nur. (2007). Faktor yang berperan dalam kegagalan praktik pemberian ASI Eksklusif (Study Kualitatif di Kecamatan Tembalang, Kota Semarang. http://eprints.undip.ac.id/17024/. Diakses tanggal 1 Agustus 2019

Ambarwati, R. (2013). Pengaruh konseling laktasi intensif terhadap pemberian air susu ibu (ASI) eksklusif sampai 3 bulan. Tesis. Vol. 2, No. 1.

Anita Liliana, Wenny Artanti N, Elsi Dwi H. (2017). Pengaruh Konseling Laktasi Terhadap Pengetahuan, Kemampuan dan Keberhasilan Ibu dalam Pemberian ASI. Berita Kedokteran Masyarakat (BKM Journal of Community Medicine and Public Health). volume 33 Nomor 2 Halaman 91-96.

Depkes. (2011). Materi advokasi-BBL kematian bayi. 17 Mei 2018. http://www.gizikiz.depkes.go.id. mencari informasi terkait proses menyusui yang benar atau motivasi ibu dalam menyusui bayi (Hanifah, Astuti \& Susanti, 2017).

\section{KESIMPULAN DAN SARAN}

\section{Kesimpulan}

Berdasarkan hasil penelitian yang dilaksanakan, maka dapat disimpulkan bahwa pendampingan dan konseling ASI berpengaruh secara signifikan terhadap pengetahuan, motivasi, dan perilaku ibu dalam menyusui. Hal ini dapat diketahui dari kenaikan yang signifikan rata-rata skor pengetahuan, motivasi, dan perilaku ibu setalah diberikan pendampingan dan konseling laktasi.

\section{Saran}

Berdasarkan hasil penelitian dan pembahasan sebelumnya, maka saran yang dapat diajukan adalah perlunya keterlibatan keluarga dalam proses pendampingan dan konseling ASI.

Deswani, D. and Mulyanti, Y. (2017). Inovasi Pendampingan Pemberian Asi Pada Ibu Pascasalin Meningkatkan Pengetahuan, Sikap Dan Perilaku Ibu Menyusui. Jurnal Ilmu Dan Teknologi Kesehatan, 5(1), pp.67-78.

Dirjen Bina Gizi dan Balita. (2013). Pekan ASI sedunia. http://www.gizikia.depkes. go.id/archives/8659. diperoleh pada tanggal 15 Maret 2018.

Dinas Kesehatan Kabupaten Probolinggo. (2017). Profil Kesehatan Kabupaten Probolinggo 2017. Diakses tanggal 1 September 2018.

Faridah, S. (2017). Perbedaan Pengetahuan Tehnik Menyusui Sebelum dan Sesudah Penyuluhan. Indonesian Journal for Health Sciences, 1(1), pp.17-22.

Hanifah, S.A., Astuti, S. and Susanti, A.I.. (2017). Gambaran Karakteristik Ibu Menyusui Tidak Memberikan Asi Eksklusif Di Desa Cikeruh Kecamatan Jatinangor Kabupaten 
Sumedang Tahun 2015. Jurnal Sistem Kesehatan, 3(1).

(2011). Konselor Bantu Tingkatkan Keberhasilan Pemberian ASI. Jakarta: Pusat komukasi Publik, Sekretariat Jenderal Kementerian Kesehatan RI. http://www.depkes.go.id (Diunduh tanggal 23 Juni 2018).

Listyaningrum, T.U. and Vidayanti, V. (2016). Tingkat Pengetahuan dan Motivasi Ibu Berhubungan dengan Pemberian ASI Eksklusif pada Ibu Bekerja. Jurnal Ners dan Kebidanan Indonesia, 4(2), pp.55-62.

Mariani dan Hamim, Nur. (2018). Pengaruh konseling menyusui terhadap motivasi, sikap dan keberhasil ibu dalam menyusui. Jurnal Ilmu Keperawatan Indonesia (JIKI) Universitas Sahid Surakarta, 12 (1).
Merdhika, W.A.R., Mardji, M. and Devi, M., (2014). Pengaruh Penyuluhan ASI Eksklusif terhadap Pengetahuan Ibu tentang ASI Eksklusif dan Sikap Ibu Menyusui di Kecamatan Kanigoro Kabupaten Blitar. Teknologi Kejuruan: Jurnal Teknologi, Kejuruan, dan Pengajarannya, 37(1).

Sri Mulyani, (2016). Pengaruh konseling menyusui terhadap sikap menyusui ibu postpartum yang dirawat. MJ, Volume 4, Nomor 1, Mei 2016, Hal: 28 - 38.

V Vidayanti, M Wahyuningsih. (2017). Efektifitas Konseling laktasi Terhadap Efikasi Diri dan Kemampuan Menyusui Ibu pasca Bedah Sesar. Jurnal Keperawatan Respati Yogyakarta, 4 (2), 154-162. 